(C) 2018 Sipayung, Anzelina. This article is distributed under the terms of CC AttributionShareAlike 4.0 International as described at https://creativecommons.org/licenses/by-sa/4.0/

UDC: 37.07

\title{
THE MODULE DEVELOPMENT OF REALISTIC MATHEMATICS APPROACH TO IMPROVE NUMBER PROBLEM SOLVING ABILITY
}

\author{
Tetty Natalia Sipayung \\ Lecturer in Mathematics Education, \\ Catholic University of Saint Thomas, Medan, Indonesia \\ ORCID: 0000-0002-3339-7126, e-mail: tettysipayung83@gmail.com \\ Dewi Anzelina \\ Lecturer in Primary School Teacher Education, \\ Catholic University of Saint Thomas, Medan, Indonesia \\ ORCID: 0000-0002-9303-5477, e-mail: dewianzelina1988@gmail.com
}

This study was conducted to know; (1) the validity of module development in realistic mathematics approach to improve the ability of solving problem in numbers; (2) the learning effectiveness of using realistic mathematics approach module to improve solving problem ability in numbers. This study used Dick and Carry development model. The subject was VII-B grade students of Nusantara Lubuk Pakam 2018/2019, while the object was the realistic mathematic approach module. The module was based on four problems solving indicators, including: understanding problem, devising plan, carrying out the plan and checking back the obtained result. The result showed that realistic mathematic approach module was valid based on the media standard, including the graphic aspect with 3.87 average score and the language aspect with 3.76 average score. Further, based on the material standard reviews, content expediency rose with 3.71 of the average score, 3.97 for presentation aspect and 4 for contextual scoring aspect. In addition, using realistic mathematic approach module was effective in enhancing the problem solving ability. The learning effectiveness was analyzed based on the students' activity and teachers' ability in maintaining the learning process and the students' problem solving ability. The average score for students' activity was 3.8 and 4.27 for teachers' ability in maintaining the learning process, categorized as good 7. Meanwhile, the result of students' problem solving ability test using realistic mathematic approach module showed 75.49 score which was higher than learning without using module, 57.59 score.

Key words: module; realistic mathematic; problem solving; education; learning strategy 
Стаття відображає дослідження, здійснене щуоб обгрунтувати розробку модуля щодо покращення здатності розв'язувати задачі за допомогою реалістичного підходу 6 математиці; підтвердити ефективність навчання з використанням такого модуля та реалістичного підходу $b$ математиці для покращення здатності розв'язувати задачі. У статті представлено модель розвитку Діка і Каррі, яка Використовувалася при дослідженні зазначених завданъ. Предметом дослідження стали досягнення учнів 7-Б класу школи Nusantara Lubuk Pakam, a об'єктом - модуль 3 Використанням реалістичного підходу $b$ математиці. Зазначении модуль об'єднав чотири основні індикатори розб'язанняя задач, а саме: ознайомлення із задачею, розробка плану розб'язання, сам розвязок та перевірка отриманого результату. Дослідження показало, що модуль з використання реалістичного підходу 8 математиці є ефективним (графічний аспект - середній бал 3,87, мовний аспект - 3,76). Крім того, використання модуля реалістичного підходу В математиці сприяє підвищенню здатності до розб'язання задач. Досліджено, що успішність учнів залежить від їхньої активності та здатності розь'язувати задачі у процесі навчання. Середній бал активності учнів становив 3,8, В той час, як середній бал здатності вчителів скеровуВати навчальний процес складає 4,2.

Ключові слова: модуль; реалістичний підхід $в$ математиці; розв'язання задач; освіта; стратегія навчання

\section{Introduction}

An effective learning depends on a good and structured teaching material. Nurhidayati, Tayeb, and Baharuddin stated that teaching material is a material which arranged by teacher for teaching and learning process in the class [1, p.240]. It cannot be denied that teaching material is one of the important things since it is the part of knowledge transfer. Teaching material can be an obstacle for a teacher; as Sunarti in Yulia, Hasan, and Fauzi put it, 'it is a hindrance factor for a teacher, either in planning the lesson or in teaching the lesson, which has impact towards students' $[2$, p.206]. Most of the teachers used teaching materials in a form of a published book, and did not use their own written material. Though, the level of students' cognitive and thinking ability is different; therefore, teachers actually should write their own teaching materials based on their expertise. Similarly, Lasmiyati and Harta, Idris stated that to run the teaching and learning process well, teaching materials must be written by the teacher [3, p.163].

In the article, teaching material designed by a teacher is called a module which is specially designed for each meeting.

The headmaster of Nusantara Lubuk Pakam Junior High School, Mr. Elwin Rizapahlepi, S.Pd, interviewed for this study, mentioned that almost $100 \%$, teachers did not use their own teaching materials in a form of module for teaching and learning process. The results of observing teachers, especially mathematics teachers, in Nusantara Lubuk Pakam Junior High School, prove that most of the teachers are not able to write a good and correct module yet.

The materials they develop lack writing systematic arrangement, including main competence, basic competence, concept, objective learning, learning activity, 
material, exercise or test, summary and the test answers key. Indris and Silalahi stated that problem solving is often found in mathematic narrative question [7, p.74]. Polya in Marlina define four steps for students to solve the mathematic problems, such as: (1) understand the problem; (2) devise a plan; (3) carry out the plan; and (4) check back the result [8].

Further, the module's cover must be designed as catchy as possible. Since, mathematic is related to everyday activities it should be designed using realistic mathematic approach. Indriani and Imanuel stated that realistic mathematic lesson is an approach in mathematic field helping students to understand the material from abstract to concrete [4, p.257-258]. It is in line with Andriani who stated that learning process with realistic mathematic approach is referring to the presentation of contextual problems in everyday activity, which leads students to knowing the importance of mathematics and gives them experience and stimulates their problem solving ability [5, p.215].

Zulkardi in Hendri, Zulkardi, and Ilma claimed that to make the mathematic lesson more meaningful and attractive for students, teachers are expected to deliver the contextual and realistic problems [6]. This is one of the important factors of a mathematics lesson. Moreover, the problem of arranging teaching materials was also caused by the lack support from school. Generally, module arrangement is done only once in a semester but if there is a revision, it will be republished in the next edition. Actually, publishing the designed module is not obligatory as long as it can be used for students in solving problems. Therefore, a module is very effective and flexible.

Based on the mentioned above, the research on module development is needed to increase students' ability in solving mathematic numbers problem. Fatikhah, Ismu and Izzati, Nurma stated that arranging module needs to hold on the principal of the module developed by following the steps in making the module itself [9, p.05]. The developed module will be validated by experts and tested in learning process to measure the effectiveness. The success of the learning process depends on how teachers manage the class [10, p.206]. Hence, learning effectiveness is reviewed from students' activity, teachers' ability in managing the teaching process and the ability to solve students' mathematic problems in number.

\section{Material \& Method}

This study was a development research, since it developed teaching material as module. It was held in Nusantara Lubuk Pakam Junior High School, with seventh grade B students of 2018/2019. Then, the object of this study was the module with realistic mathematic approach to improve the ability of number problem solving.

The instruments in this study were observation sheet and ability test of mathematic problem solving. The test was designed in four indicators of problem solving, including: understanding problem, devising a plan, carrying out the plan and checking back the result. The test was in the form of essay with eight materials test as seen in the table 1 below:

Table 1. Test Material

\begin{tabular}{|c|c|c|}
\hline No. & Test Material & Number of Question \\
\hline 1. & Knowing and Comparing the Integers & 3 \\
\hline 2. & Integers Addition and Subtraction & 4 \\
\hline
\end{tabular}




\begin{tabular}{|c|c|c|}
\hline 3. & Integers Multiplication and Division & 4 \\
\hline 4. & Knowing and Comparing the Fractions & 3 \\
\hline 5. & Fraction Addition and Subtraction & 4 \\
\hline 6. & Fraction Multiplication and Division & 3 \\
\hline 7. & Positive Integers Exponents & 3 \\
\hline 8. & $\begin{array}{c}\text { Less Common Multiple and Greatest } \\
\text { Common Divisor }\end{array}$ & 2 \\
\hline
\end{tabular}

The data collection techniques were divided into two, they were: non-test technic by observation and test technique. The data analyses were validity analysis and module rehabilitation. Besides, the effective analysis was needed based on the observation sheet and ability test in problem solving. Furthermore, the module design was developed based on Dick and Carrey model.

\section{Result and Discussion}

The development steps in Dick and Carrey model were explained as the following points below.

\section{Problem Identification}

The needs analysis was done based on the actual situation in the class to identify problems. It was done through interview with students on the problems they had faced related to teaching materials and learning process in the class. Through the interview with students, the used book had many problems to be solved. However, there was not enough time to solve the problems because there were too many of them and they required high comprehension abilities. After that, the teachers were analyzed through interviewing them regarding the obstacles faced in making the module as the teaching materials. From the interview, it was found out that teachers' obstacles to making the module occurred when they were not aware of the techniques of arranging it. It happened since teachers had never joined any workshop or training of arranging modules. Thus, the teaching materials they had used were the materials from publishers sold to the students. Further, the learning process was analyzed through interviewing the students. The result showed that the learning process applied by teacher was monotonous and unattractive. Thus, for reaching the purpose, it is important that the needs, teacher and learning process should be analyzed.

2. Curriculum Analysis

Based on the interview with the headmaster and the curriculum staff, it was found out that Nusantara Lubuk Pakam Junior High School applied curriculum of 2013 (K13). However, the learning process did not meet the curriculum demands. To improve the situation, the module was developed based on the core and the basic competence in curriculum 2013 syllabus. The designed teaching material was linked to the learning objectives in order to make the material not deviated from the initial purposes. Learning objectives were made to know the degree of students in mastering the ability after getting class.

\section{Design}

This step was used to design the tools and the module. The tools included a validation module sheet, students' observation sheet, teachers' observation sheet in managing the learning process and the ability test of students' problem solving. They 
were used to validate and to collect the data by using the module in learning process. The Lesson plan applied in this module development was realistic mathematic approach.

\section{Publication}

After the initial module text has been produced, the module and the ability test of problem solving were validated by the experts. The test had already been validated by the experts and trialed on non-research subject students. Then, the module validation and trial test result were analyzed and revised based on the validators' suggestion and the trial test result. The explanation could be seen in figure 1 below:
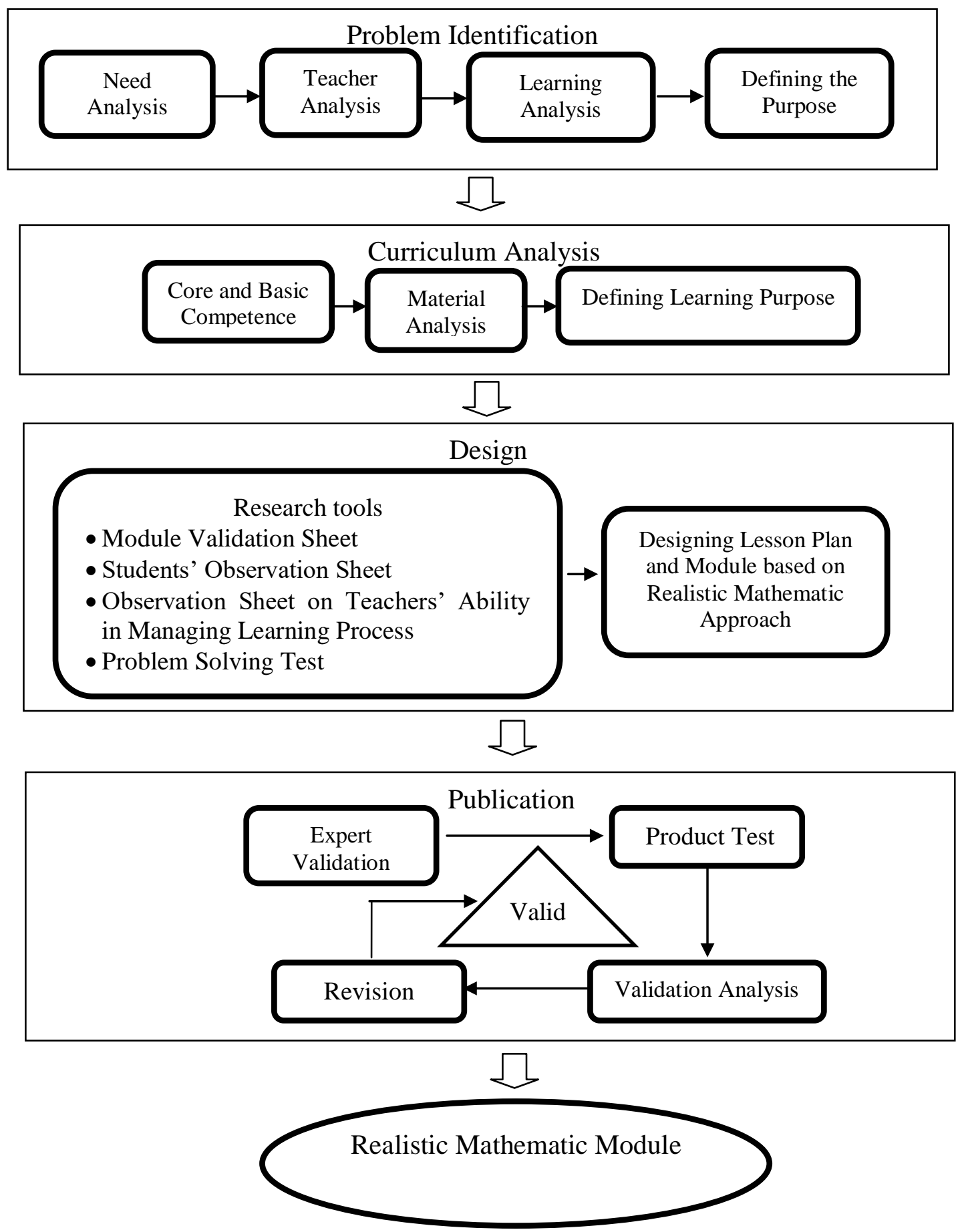

Figure 1. Module Development Steps with Dick and Carrey 
The validation result of module development was obtained through the steps of developing the module. It could be seen in the 2 below:

Table 2. The Validation Result of Numerical Module A. The Standard of Module

\begin{tabular}{|c|c|c|c|}
\hline No. & Aspect & Average & $\begin{array}{l}\text { Validation } \\
\text { Criteria }\end{array}$ \\
\hline \multirow{4}{*}{1.} & Graphic & 3,87 & \multirow[t]{4}{*}{ Valid } \\
\hline & A. Module size & 4 & \\
\hline & B. Material accuracy & 3.69 & \\
\hline & C. Contain design & 3.92 & \\
\hline \multirow{7}{*}{2.} & Language & 3.76 & \multirow[t]{7}{*}{ Valid } \\
\hline & A. Simple & 3.83 & \\
\hline & B. Communicative & 4 & \\
\hline & C. Dialogic and Interactive & 4 & \\
\hline & $\begin{array}{lll}\begin{array}{l}\text { D. Suitable } \\
\text { development }\end{array} & \text { with students' } \\
\end{array}$ & 3.25 & \\
\hline & E. Language principle compatibility & 3.75 & \\
\hline & F. Symbol and icon usage & 3.75 & \\
\hline
\end{tabular}

\section{B. Standard of Module Material}

\begin{tabular}{|l|l|l|l|}
\hline \multirow{4}{*}{ No. } & Aspek & Average & $\begin{array}{l}\text { Validation } \\
\text { Criteria }\end{array}$ \\
\hline \multirow{4}{*}{1.} & Contain & 3.71 & Valid \\
\cline { 2 - 3 } & $\begin{array}{l}\text { A. Compatible with Standard and Basic } \\
\text { Competency }\end{array}$ & 3.33 & \\
\cline { 2 - 3 } & B. Material accuracy & 3.86 & \\
\cline { 2 - 3 } & C. Improved material & 3.90 & \multirow{4}{*}{ Valid } \\
\cline { 2 - 3 } & D. Encourage curiosity & 3.75 & \\
\cline { 2 - 3 } 2. & Presentation & 3.97 & \multirow{2}{*}{ Very Valid } \\
\cline { 2 - 3 } & A. Presentation technic & 4 & \\
\cline { 2 - 3 } & B. Supporting presentation & 3.87 & \\
\cline { 2 - 3 } & C. Learning presentation & 4 & \\
\hline \multirow{2}{*}{3.} & D. Coherence and Cohesion & 4 & \\
\hline & A. Contextual Term & 4 & \\
\hline & B. Contextual Component & \multicolumn{1}{|}{} \\
\hline
\end{tabular}

On the other sides, the effectiveness of learning process using module was analyzed based on the students' activity and the teachers' ability in managing the 
lesson and the ability test result. The data of students' activity group using realistic mathematic module could be seen in table 3 below:

Table 3. The Average Data of Students Activity Group

\begin{tabular}{llll}
\hline No. & Material & Score & Category \\
\hline 1. & Knowing and Comparing the Integers & 3.76 & Good \\
\hline 2. & Integers Addition and Subtraction & 3.83 & Good \\
\hline 3. & Integers Multiplication and Division & 3.85 & Good \\
\hline 4. & Knowing and Comparing the Fraction & 3.85 & Good \\
\hline 5. & Fraction Addition and Subtraction & 3.83 & Good \\
\hline 6. & Fraction Multiplication and Division & 3.76 & Good \\
\hline 7. & Positive Integers Exponents & 3.76 & Good \\
\hline $\begin{array}{l}\text { 8. Less Common Multiple and Greatest } \\
\text { Common Divisor }\end{array}$ & & Good \\
\hline \multicolumn{2}{l}{ Rata-Rata } & 3.81 & Good \\
\hline
\end{tabular}

Based on the observation, the average data of teachers' ability in managing the learning process using realistic mathematic module presented in each material could be seen in table 4 below:

Table 4. The Average Data of Teacher Ability in Managing Learning Process

\begin{tabular}{llll}
\hline No. & Material & Score & Category \\
\hline 1. & Knowing and Comparing Integers & 4.17 & Good \\
\hline 2. & Integers Addition and Subtraction & 4.33 & Good \\
\hline 3. & Integers Multiplication and Division & 4.33 & Good \\
\hline 4. & Knowing and Comparing Fraction & 4.33 & Good \\
\hline 5. & Fraction Addition and Subtraction & 4.17 & Good \\
\hline 6. & Fraction Multiplication and Division & 4.33 & Good \\
\hline 7. & Positive Integers Exponents & 4.17 & Good \\
\hline 8. & Less Common Multiple and Greatest & 4.33 & Good \\
\hline Total Average & & \\
\hline
\end{tabular}

The Minimum Mastery Criteria (KKM) in school was set for 72 . Therefore, the problem solving test result given to students with realistic mathematic module in their learning process could be seen in the table 5 below:

Table 5. The Average Data of Students Problem Solving Ability with Realistic Mathematic Module

\begin{tabular}{llll}
\hline No. & Material & $\begin{array}{l}\text { Learning } \\
\text { Percentage }\end{array}$ & $\begin{array}{l}\text { Average } \\
\text { Score }\end{array}$ \\
\hline 1. & Knowing and Comparing Integers & $72 \%$ & 7231 \\
\hline 2. & Integers Addition and Subtraction & $80 \%$ & 78.76 \\
\hline 3. & $\begin{array}{l}\text { Integers Multiplication and } \\
\text { Division }\end{array}$ & & $86 \%$ \\
\hline 4. & Knowing and Comparing Fraction & $77 \%$ & 72.42 \\
\hline
\end{tabular}




\begin{tabular}{llll}
\hline 5. & Fraction Addition and Subtraction & $77 \%$ & 73.36 \\
\hline $\begin{array}{l}\text { Fraction Multiplication and } \\
\text { Division }\end{array}$ & $77 \%$ & 74.67 \\
\hline $7 . \quad$ Positive Integers Exponents & $80 \%$ & 75.39 \\
\hline 8. $\begin{array}{l}\text { Less Common Multiple and } \\
\text { Greatest Common Divisor }\end{array}$ & $80 \%$ & 75.75 \\
\hline Total Average & $78,63 \%$ & 75.49 \\
\hline
\end{tabular}

Meanwhile, the result of problem solving test given to students without using realistic mathematic module in their learning process could be seen in the table 6 below.

Table 6. The Average Data of Students Problem Solving Ability without Realistic

\begin{tabular}{|c|c|c|c|}
\hline & & & lathemat \\
\hline No. & Material & Learning & Average \\
\hline 1. & Knowing and Comparing Integers & $22 \%$ & 51.97 \\
\hline 2. & Integers Addition and Subtraction & $58 \%$ & 59.25 \\
\hline 3. & $\begin{array}{lll}\text { Integers } & \text { Multiplication } & \text { and } \\
\text { Division } & & \end{array}$ & $38 \%$ & 55.36 \\
\hline 4. & Knowing and Comparing Fraction & $42 \%$ & 56.53 \\
\hline 5. & Fraction Addition and Subtraction & $53 \%$ & 60.67 \\
\hline 6. & $\begin{array}{lll}\text { Fraction } & \text { Multiplication } & \text { and } \\
\text { Division } & & \end{array}$ & $55 \%$ & 53.78 \\
\hline 7. & Positive Integers Exponents & $39 \%$ & 52.06 \\
\hline 8. & $\begin{array}{l}\text { Less Common Multiple and } \\
\text { Greatest Common Divisor }\end{array}$ & $69 \%$ & 71.11 \\
\hline Tota & Average & $47 \%$ & 57.59 \\
\hline
\end{tabular}

\section{Conclusion}

In short, this study has proved that the realistic mathematic approach module of number with Dick and Carrey model was valid. It could be seen through the media standard, including the graphical aspect with 3.87 average score and the language aspect with 3.76 average score. Further, it was reviewed based on the material standard that the content aspect got 3.71 average score, 3.7 for presentation aspect and 4 for contextual scoring aspect. The realistic mathematic approach module was effective to improve the students' problem solving ability. It was seen from the average score of students' activity for 3.81 and teachers' ability in maintaining the learning process for 4.27 categorized as good. Meanwhile, the result of students' problem solving ability test using realistic mathematic approach module in their learning process obtained 75.49 higher than the students who did not use the module in their learning process which was 57.59 .

\section{Acknowledgement}

A million thanks to Directorate General of Strengthening Research and Development, Ministry of Research, Technology and Higher Education, based on the 
contract letter for beginner lecturer research Number 227/K.1.1./LT.1/2018 for funding and making the research work well and the result could be published through this writing. Moreover, the writers also thank to Private High Education Regional Coordinator I and Institute for Research and Community Services of Santo Thomas Catholic University for the support.

\section{References:}

1. Nurhidayati, S., Tayeb, T., and Baharuddin. Pengembangan Bahan Ajar Matematika Berbasis Masalah Untuk Memfasilitasi Pencapian Kemampuan Penalaran Pada Pokok Bahasan Perbandingan Kelas VII MTSN Model Makassar. MaPan: Jurnal Matematika dan Pembelajaran. 2017; 5(2): 236-250.

2. Yulia, L., Hasan, B., and Fauzi. Kendala Guru Dalam Mengimplementasikan Buku Paket Kurikulum 2013 di SD Negeri 50 Banda Aceh. Jurnal Ilmiah Pendidikan Guru Sekolah Dasar FKIP Unsyiah. 2017; 2(1):204-211.

3. Lasmiyati and Harta, Idris. Pengembangan Modul Pembelajaran Untuk Meningkatkan Pemahaman Konsep dan Minat SMP. Phytagoras: Jurnal Pendidikan Matematika. 2014; 9(1):161-174.

4. Indriani, M.N, and Imanuel. Pembelajaran Matematika Realistik Dalam Permainan Edukasi Berbasis Keunggulan Lokal Untuk Membangun Komunikasi Matematis. Prisma: Prosiding Seminar Nasional Matematika. 2018; 256-262.

5. Andriani, V. Penerapan Pendekatan Pembelajaran Matematika Realistik Untuk Meningkatkan Pamahaman Siswa Pada Materi Soal Cerita Pecahan di Kelas VII MTs Alkhairaat Tondo. Jurnal Eleketronik Pendidikan Matematika Tadulako, 2014; 01(02): 214-224.

6. Hendri, D., Zulkardi, and Ilma, R. Pengembangan Materi Kesebangunan Dengan Pendekatan PMRI di SMP Negeri 5 Talang Ubi. Jurnal Pendidikan Matematika. 2007; 1(2):46-55.

7. Idris, I., and Silalahi, D.K. Penerapan Pendekatan Pendidikan Matematika Realistik Indonesia (PMRI) Untuk Meningkatkan Kemampuan Penyelesaian Soal Cerita pada Kelas VIIA SMP UTY. Jurnal Edukasi Matematika dan Sains. 2016; 1(1):72-82.

8. Marlina, L. Penerapan Langkah Polya Dalam Menyelesaikan Soal Cerita Keliling dan Luas Persegi Panjang. Jurnal Elektronik Pendidikan Matematika Tadulako. 2013; 1(1):4352.

9. Fatikhah, Ismu and Izzati, Nurma. Pengembangan Modul Pembelajaran Matematika Bermuatan Emotion Quotient Pada Pokok Bahasan Himpunan. Eduma. 2015; 4(2):46-61

10. Anugraheni, I. Analisa Faktor-Faktor yang Mempengaruhi Proses Belajar Guru-Guru Sekolah Dasar. Kelola: Jurnal Manajemen Pendidikan. 2017; 4(2):205-212. 